\title{
Analyzed Quality of Senior High School Biology Olympiad Questions at West Sumatera, Riau, Jambi, and Bengkulu in 2018
}

\author{
Analisis Kualitas Soal Olimpiade Biologi SMA \\ Se-Sumatera Barat, Riau, Jambi dan Bengkulu Tahun 2018
}

\author{
Eka Aghnia Syarif ${ }^{1)}$, Syamsurizal ${ }^{1)}$ \\ 1) Jurusan Biologi, Universitas Negeri Padang \\ Jl. Prof Dr. Hamka Air Tawar Padang, Indonesia \\ Correspondence: syam_unp@fmipa.unp.ac.id
}

\begin{abstract}
The aim of this study to determine the quality of items in terms of analysis : 1) the validity of content and empirical, 2) reliability, 3) level of difficulty, 4) distinguishing features, and 5) the function of detractors. This research is a descriptive study. The sample was a set of biology olimpic question for senior high school year 2018/209 in West Sumatera, Riau, Jambi, and Bengkulu. Quantitative analysis was performed by using Anates, while for the qualitative analysis carried out by the study table. Based on the results of data analysis, the result for the review of aspects : 1) the validity of the content $52.5 \%$ are invalid matter, 2) reliability, the test has a value of 0.6 belong to the category enough, 3) the level of difficulty, $1,6 \%$ classified as very easy matter, 1,6\% easy, 36.6\% about the medium, $41,6 \%$ about the difficult, and $18.3 \%$ about the very difficult, 4) different power, $65 \%$ of matter which is classified as very bad, $28.5 \%$ about the relatively ugly, 6.6\% about enough, and $0 \%$ items good, 5) function options, for options that are not qualified humbug is $36.6 \%$ and the quality is 63,3\%. It can be concluded that the end of the senior high school biology olympiadquestions at West Sumatera, Riau, Jambi, and Bengkulu in 2018 through the 4.0 version of Anates program not meet both criteria.
\end{abstract}

Keywords: (Analysis, quality, and question)

\section{PENDAHULUAN}

Jurusan Biologi Universitas Negeri Padang menaungi kumpulan mahasiswa dalam suatu organisasi yaitu Himpunan Mahasiswa Jurusan Biologi (HIMABIO). HIMABIO INI memiliki beberapa program kerja yang dilaksnakan tiap periode, salah satunya adalah SEMNAS BIOEXO (Seminar Nasional dan Biology Exhibition).Kegiatan yang diadakan pada program kerja tersebut salah satunya adalah olimpiade biologi tingkat SMA/MA se-Sumatera Barat, Jambi, Riau, dan Bengkulu.

Olimpiade biologi adalah salah satu ajang kompetisi dalam dunia pendidikan yang memberi tempat bagi peserta didik untuk bersaing dan mengukur kemampuannya dibidang biologi.Tujuan dari kegiatan olimpiade biologi ini adalah 
untuk mengasah kemampuan peserta didik pada bidang biologi, meningkatkan mutu pembelajaran biologi, dan menjaring bibit-bibit unggul di bidang biologi. Pelaksanaan olimpiade secara berkelanjutan akan berdampak positif padapelaksanaan proses pembelajaran sehingga menjadi lebih kreatif dan inovatif (Maiza, 2013:2).Kegiatan Olimpiade secara umum dipersiapkan dengan matang, terutama terkait soal-soal yang akan diberikan pada peserta. Soal dipersiapkan agar dapatmengukur dan melatih kemampuan berfikir dan bernalar peserta.

Meskipun soal-soal yang dibuat oleh tim divisi soal tes olimpiade biologi tingkat SMA/MA sudah dikonsultasikan ke pihak dosen pembimbing, namun belum ada uji tertulis terkait kualitas soal yang disajikan. Jika soal tersebut dikerjakan maka akan menyebabkan soal tidak dapat mengukur sejauh mana kemampuan siswa yang sebenarnya. Suatu hasil olimpiade yang diperoleh dengan menggunakan tes yang tidak baik tentu bukan merupakan cermin yang sebenarnya dari prestasi belajar dan kemampuan peserta didik yang bersangkutan.

Upaya untuk mengetahui kualitas soal tes tertulis olimpiade biologi dapat dilakukan dengan menganalisis soal olimpiade biologi.Kegiatan analisis butir soal dilakukan untuk mengetahui apakah soal yang dibuat dan digunakan baik, kurang baik atau jelek sehingga dapat dilakukan tindak lanjut dan perbaikan terhadap mutu soal.Tujuan khusus darianalisis butir soal ialah untuk mencari soal tes mana yang baik dan mana yang tidak baik, dan mengapa item atau soal itu dikatakan baik atau tidak baik.Dengan mengetahui soal-soal yang tidak baik itu selanjutnya kita dapat mencari kemungkinan sebab-sebab mengapa item itu tidak baik (Purwanto, 2013: 118).Pada tes pilihan ganda, butir soal yang baik harus memiliki tingkat kesulitan yang memadai, validitas yang baik, reliabilitas, daya pembeda yang baik, dan kualitas pengecoh yang baik(Suwarto, 2016: 3).

Validitas adalah sejauh mana ketepatan dan kecermatan suatu alat ukur dalam melakukan fungsi ukurnya.Tes memiliki validitas yang tinggi jika hasilnya sesuai dengan kriteria, atau memiliki kesejajaran antara tes dan kriteria(Azwar, 2009: 5).Selain validitas juga ada tingkat kesukaran.Tingkat kesukaran adalah mudah atau sulitnya suatu butir soal bagi sekelompok peserta didik (Arikunto, 2015: 223).Tingkat kesukaran soal disesuaikan dengan tujuan dari evaluasi.Soal olimpiade memiliki tujuan untuk menyeleksi peserta didik yang unggul dibidang biologi sehingga diperlukan soal dengan tingkat kesukaran tinggi.

Reliabilitas adalah ketetapan suatu tes apabila diteskan kepada subjek yang sama.Reliabilitas tes adalah tingkat konsitensi suatu tes, yakni sejauh mana suatu tes dapat dipercaya untuk menghasilkan skor yang relatif tidak berubah walaupun diteskan pada situasi yang berbeda-beda(Miranti, dkk., 2019: 8). Daya beda soal juga menjadi aspek yang sangat penting untuk diperhatikan dalam penyusunan tes. Daya beda soal adalah kemampuan suatu soal untuk dapat membedakan antara peserta didik dengan kemampuan tinggi dan peserta didik dengan kemampuan rendah 
(Arikunto, 2015: 226). Soal dengan daya beda baik, apaila diberikan kepada anak yang mampuakan menunjukkan prestasi yang tinggi, dan bila diberikan ke anak yang lemah pengetahuannya, hasilnya rendah(Dewi, dkk., 2019: 17).

Pada tes objektif untuk setiap butir item yang dikeluarkan dalam tes hasil belajar telah dilengkapi dengan beberapa kemungkinan jawaban atau yang dikenal dengan option atau alternatif.Distractor baru dapat dikatakan telah dapat menjalankan fungsinya dengan baik, apabila telah memiliki daya tarik (Sudijono, 2012: 409-410).

Berdasarkan hasil penelitian sebelumnya tentang analisis butir soal tes tertulis olimpiade biologi tingkat SMA se-Riau dan Kepulauan Riau, diketahui bahwa soal yang digunakan untuk olimpiade biologi memiliki kualitas kurang baik. Hal ini berdasarkan klasifikasi analisis kuantitatif dari segi tingkat kesukaran, daya pembeda, efektifitas pengecoh, validitas serta reliabilitas soal, diketahui hanya 15 soal yang masuk kategori diterima, 76 soal perlu diperbaiki dan 9 soal ditolak (Miranti, dkk., 2019: 4-8).

Tujuan utama analisis butir soal dalam sebuah tes adalah untuk mengidentifikasi kekurangan dalam tes.Tes yang digunakan dalam pengambilan keputusan tentang hasil olimpiade biologi untuk tingkat SMA se-Sumatera Barat, Jambi, Riau, dan Bengkulu belum menggunakan tes yang sudah diuji coba. Adanya alat evaluasi yang telah diketahui karakteristik dan kualitasnya sangat diperlukan agar keputusan tentang hasil pra olimpiade tidak merugikan salah satu pihak.Soal yang digunakan belum mengalami proses standarisasi, maka penulis melakukan proses standarisasi soal olimpiade biologi tersebut dengan menggunakan program komputer Anates versi 4.0 for Windows. Program ini dapat menjadikan kegiatan analisis soal lebih cepat dan lebih mudah, sehingga lebih menarik.

Berdasarkan uraian yang telah dikemukakan, maka penulis tertarik untuk melakukan penelitian tentang "Analisis Kualitas Soal Olimpiade Biologi SMA SeSumatera Barat, Riau, Jambi dan Bengkulu Tahun 2018”. Dengan tujuan untuk mengetahui kualitas soal olimpiade biologi SMA se-Sumatera Barat, Jambi, Riau dan Bengkulu tahun 2018 dan sebagai evaluasi untuk pembuatan soal pada olimpiade biologi selanjutnya.

\section{METODE PENELITIAN}

Penelitian ini merupakan penelitian deskriptif kuantitatif dimana peneliti tidak memberikan perlakuan melainkan hanya memaparkan kondisi sebagaimana adanya dan mengambil kesimpulan setelah analisis.Metode pengumpulan data yang digunakan adalah dokumentasi.Metode ini dilakukan untuk mengumpulkan data berupa satu set soal olimpiade biologi tingkat SMA se-Sumatera Barat, Jambi, Riau, dan Bengkulu tahun 2018 beserta 318 lembar jawabannya. 
Populasi pada penelitian ini adalah seluruh lembar jawaban peserta olimpiade biologi SMA se-Sumatera Barat, Jambi, Riau, dan Bengkulu Tahun 2018.Sampel pada penelitian ini adalah 318 lembar jawaban peserta olimpiade biologi.Teknik yang digunakan dalam pengambilan sampel adalah teknik Proporsional Random, dan diperoleh sampel sebanyak 318 lembar jawaban. Satu set soal terdiri dari 60 butir, yang dibedakan menjadi 40 butir soal pilihan ganda biasa, 10 butir pilihan ganda kompleks/asosiasi, dan 10 butir pilihan ganda sebab akibat.

Sumber data dalam penelitian ini berasal dari data sekunder, sehingga instrumen penelitian yang digunakan adalah lembar jawaban peserta tes tertulis itu sendiri.Analisis menggunakan lembar jawaban peserta tes yang dianalisis dengan menggunakan bantuan program komputer ANATES versi 4.09 yang merupakan program aplikasi komputer untuk menganalisis butir soal pilihan ganda dari segi validitas, reliabilitas, tingkat kesukaran, daya pembeda, dan fungsi opsi.

\section{HASIL PENELITIAN DAN PEMBAHASAN}

\section{A. Hasil}

\section{Validitas}

Validitas butir soal digunakan untuk mengetahui dukungan suatu butir soal terhadap skor total. Untuk menguji validitas setiap butir soal, skor-skor yang ada pada butir soal yang dimaksud dikorelasikan dengan skor total. Sebuah soal akan memiliki validitas yang tinggi jika skor soal tersebut memiliki dukungan yang besar terhadap skor total. Dari hasil olahan Anates versi 4.0 for Windows diperoleh soal yang termasuk kategori valid berjumlah 17 butir dengan persentase $28,3 \%$, dan soal yang termasuk kategori tidak valid berjumlah 43 butir dengan persentase $71,7 \%$.

\section{Reliabilitas}

Hasil uji reliabilitas soal yang diperoleh adalah 0,60. Angka reliabilitas ini menunjukkan soal tergolong pada kategori cukup, dan soal sudah reliabel.

\section{Tingkat Kesukaran}

Hasil analisis tingkat kesukaran diketahui bahwa 1 butir soal termasuk kategori sangat mudah, 1 butir soal termasuk kategori mudah, 22 butir soal termasuk kategori sedang, 25 butir soal termasuk kategori sukar, dan 12 butir soal termasuk kategori sangat sukar. Berdasarkan analisis tingkat kesukaran dapat disimpulkan bahwa $1,66 \%$ soal tergolong sangat mudah, $1,66 \%$ soal tergolong mudah, dan $36,66 \%$ butir soal tergolong sedang, dan $40 \%$ soal tergolong sukar. Distribusi tingkat kesukaran soal dapat dilihat pada Tabel 1. 
Tabel 1. Kategori Tingkat Kesukaran Butir Soal

\begin{tabular}{cccc}
\hline Kategori & Nomor Soal & Jumlah & $\begin{array}{c}\text { Persentase } \\
(\%)\end{array}$ \\
\hline $\begin{array}{c}\text { Sangat } \\
\text { mudah }\end{array}$ & 37 & 1 & 1,66 \\
\hline Mudah & 36 & 1 & 1,66 \\
\hline Sedang & $4,5,8,11,13,15,17,18,21,22,23,24$, & 22 & 36,66 \\
& $25,29,32,34,39,45,46,51,56,58$ & & \\
\hline Sukar & $1,6,7,9,10,12,14,16,19,28,30,33$, & 24 & 40,00 \\
& $38,40,41,42,43,44,47,48,50,57,56$, \\
60 & & 20,00 \\
\hline $\begin{array}{c}\text { Sangat } \\
\text { Sukar }\end{array}$ & $2,3,20,26,27,31,35,49,52,54,55,59$ & 12 & \\
\hline
\end{tabular}

\section{Daya Pembeda}

Hasil analisis daya pembeda soal diketahui bahwa 39 butir soal termasuk kategori sangat jelek, 17 butir soal termasuk kategori jelek, 4 butir soal termasuk kategori cukup, dan tidak ada satu butir soal pun yang termasuk kategori baik. Berdasarkan analisis daya pembeda dapat disimpulkan bahwa $65 \%$ soal yang tergolong sangat jelek, $28,33 \%$ soal jelek, dan $6,66 \%$ butir soal cukup. Distribusi daya pembeda soal dapat dilihat pada Tabel 2.

Tabel 2. Kategori Daya Beda Butir Soal

\begin{tabular}{|c|c|c|c|}
\hline Kategori & Nomor Soal & Jumlah & $\begin{array}{c}\text { Persentase } \\
(\%)\end{array}$ \\
\hline Sangat jelek & $\begin{array}{c}1,2,3,6,7,9,10,12,16,18,20,22,25 \\
26,27,28,30,31,33,35,36,38,40,41 \\
42,43,44,45,46,47,48,49,50,52,54 \\
55,57,59,60\end{array}$ & 39 & 65,00 \\
\hline Jelek & $\begin{array}{c}4,11,13,14,15,17,19,23,24,32,34 \\
37,39,51,53,56,58\end{array}$ & 17 & 28,33 \\
\hline Cukup & $5,8,21,29$ & 4 & 6,66 \\
\hline Baik & - & - & - \\
\hline
\end{tabular}

\section{Fungsi Opsi}

Hasil analisis kualitas opsi didapatkan soal dengan kualitas opsi pengecoh yang tidak berkualitas adalah $36,6 \%$ dan yang berkualitas adalah $63,3 \%$. 


\section{B. PEMBAHASAN}

\section{Validitas}

Hasil analisis validitas diketahui bahwasoal yang termasuk kategori valid berjumlah 17 butir dengan persentase 28,3\%, dan soal yang termasuk kategori tidak valid berjumlah 43 butir dengan persentase $71,7 \%$. Butir soal yang memiliki nilai validitas tinggi mencerminkan soal tersebut telah baik dan tidak perlu diragukan ketepatannya dalam mengukur kemampuan peserta didik. Soal yang dikatakan valid adalah soal yang mengukur setiap aspek berpikir dan soal yang telah memiliki korelasi positif dengan skor total (Sari, 2016: 8).

\section{Reliabilitas}

Tes dikatakan reliabel jika suatu tes dapat mengukur secara konsisten sesuatu yang akan diukur dari waktu ke waktu. Tes reliabel jika suatu tes memiliki kemampuan untuk menghasilkan pengukuran yang tetap, tidak berubah jika digunakan secara berulang-ulang pada sasaran yang sama. Dengan kata lain jika kepada para peserta didik diberikan tes yang sama pada waktu yang berlainan, maka setiap peserta didik akan tetap berada dalam urutan yang sama dalam kelompoknya.

Berdasarkan hasil analisis reliabilitas, nilai reliabilitas yang dimiliki tes ini adalah sebesar 0,60, artinya konsistensi dan kestabilan soal tes termasuk kategori sedang. Konsistensi dan kestabilan soal ini dilihat dari jawaban peserta tes tertulis. Tinggi rendahnya reliabilitas ditunjukkan oleh koefisien korelasi antara dua tes yang paralel, yang dikenakan pada sekelompok individu yang sama (Azwar, 2009: 8).Nilai reliabilitas pada rentangan 0,40-0,69 artinya memiliki reliabilitas yang sedang. Angka ini menunjukkan bahwa tes sudah memiliki reliabilitas namun masih belum tinggi, koefisien tinggi menunjukkan reliabilitas tinggi dan sebaliknya (Sukardi, 2012: 53).

\section{Tingkat Kesukaran}

Hasil analisis tingkat kesukaran soal diketahui bahwa $1,66 \%$ soal olimpiade biologi tergolong sangat mudah, $1,66 \%$ soal tergolong mudah, $36,66 \%$ soal tergolong soal sedang, $40 \%$ soal tergolong sukar, dan $20 \%$ soal tergolong sangat sukar. Secara keseluruhan soal sukar dan sangat sukar jika ditotal hampir seimbang. Sama halnya dengan soal mudah dan sangat mudah jika ditotal maka hasilnya juga sama. Hasil analisis ini menunjukkan bahwa soal yang digunakan pada olimpiade biologi 2018 telah sesuai karena sudah menggunakan soal-soal dengan tingkat kesukaran tinggi.Kriteria soal yang baik adalah butir soal yang tidak terlalu mudah dan terlalu sukar. Soal yang sangat mudah tidak merangsang peserta didik untuk mempertinggi usaha memecahkan butir soal. Soal dengan kriteria mudah sebaiknya berfikir dan sebaiknya tidak digunakan sebagai soal olimpiade (Arikunto, 2015:223). 


\section{Daya Beda}

Hasil analisis daya beda butir soal, diketahui bahwa 39 butir soal atau sebesar $65 \%$ soal termasuk kriteria jelek sekali. Sebanyak 17 butir soal atau sebesar 28,33\% soal termasuk kriteria jelek, 4 butir soal atau sebesar $6,66 \%$ soal termasuk kriteria cukup, dan tidak ada soal yang memiliki atau termasuk kriteria baik. Soal yang baik dapat membedakan siswa yang memiliki kemampuan yang tinggi (pandai) dan kemampuan rendah.Soal yang baik adalah soal yang lebih banyak bisa dijawab oleh siswaberkemampuan tinggi daripada siswa yang berkemapuan rendah, sehingga dapat membedakan antara keduanya (Anita, dkk,. 2014: 21).

Daya beda soal adalah pengukuruan sejauh mana suatu butir soal mampu membedakan peserta didik yang sudah mampu mengusai kompetensi dengan peserta didik yang belum menguasai kompetensi. Daya pembeda suatu soal dapat dikatakanbaik apabila berada pada kriteria baik.Soal yang digunakan sebaiknya adalah soal yang memiliki daya pembeda baik dan cukup baik, sedangkan soal yang memiliki daya pembeda jelek sebaiknya direvisi atau tidak digunakan (Arikunto 2015: 232). Soal yang tidak dapat membedakan peserta didik yang pandai dengan yang kurang pandai disebabkan oleh beberapa kemungkinan, diantaranya kunci jawaban tidak tepat, terdapat dua atau lebih jawaban benar, kompetensi yang diukur tidak jelas, pengecoh tidak berfungsi, dan materi yang ditanyakan terlalu sulit (Sofiana, 2010: 89).

\section{Fungsi Opsi}

Hasil analisis fungsi opsi diketahui 63,3\% fungsi opsi sudah efektif, dan $36,6 \%$ belum efektif. Persentase tersebut diperoleh dengan membandingkan opsi pengecoh yang masuk kriteria efektif atau tidak efektif dengan keseluruhan opsi pengecoh.Berdasarkan hasil analisis tersebut dapat disimpulkan bahwa kualitas opsi pengecoh pada soal olimpiade ini baik, karena pengecoh soalnya berkualitas sehingga dapat berfungsi juga dengan baik.Suatu pengecoh dianggap baik bila jumlah peserta didik yang memilih pengecoh itu sama atau mendekati jumlah ideal (Arifin, 2014: 279).

Pada opsi jawaban terdapat dua jenis opsi yaitu opsi kunci dan opsi pengecoh.Opsi pengecoh bukan hanya sekedar pelengkap jawaban, tetapi memang sengaja dibuat untuk mengecoh peserta didik yang tidak paham dengan materi.Oleh sebab itu opsi pengecoh yang baik harus homogen dengan kunci, atau dibuat semirip mungkin dengan kunci jawaban. Pengecoh yang buruk adalah pengecoh yang sama sekali tidak dipilih oleh peserta didik. Soal dengan nilai pengecoh yang kurang dari 5\% merupakan soal yang kurang baik, karena fungsi pengecoh pada soal tersebut belum dapat mengelabui peserta didik yang kurang memahami materi tes yang diujikan (Miranti, dkk., 2019: 7).

Soal yang termasuk kategori baik adalah soal yang memiliki tingkat kesukaran dari sedang hingga sangat sukar, memiliki daya pembeda baik atau cukup baik, distraktor efektif, valid dan reliabel.Soal yang masih memerlukan revisi adalah 
soal yang sudah termasuk kategori baik tetapi masih memiliki distraktor yang belum efektif.Sedangkan soal yang termasuk kategori jelek adalah soal yang tidak valid.Soal yang termasuk kategori jelek sebaiknya tidak digunakan untuk olimpiade. Hal ini karena soal tersebut tidak dapat mengukur kemampuan peserta tes dengan baik (Nurinda, dkk,. 2014: 80).

\section{PENUTUP}

Berdasarkan hasil penelitian diatas, diketahui bahwa soal yang valid sebanyak 17 butir soal, dan soal yang tidak valid sebanyak 43 butir soal. Jumlah total butir soal sebanyak 60. Hasil uji reliabilitas soal yang diperoleh adalah 0,60. Angka reliabilitas ini menunjukkan soal tergolong pada kategori sedang dan soal sudah reliabel.Hasilanalisis tingkat kesukaran soal diketahui bahwa Hasil analisis tingkat kesukaran soal diketahui bahwa 1 butir soal atau sebesar $1,66 \%$ soal olimpiade biologi tergolong sangat mudah, 1 butir soal atau 1,66\% soal tergolong mudah, 22 butir soal atau 36,66\% soal tergolongsedang, 24 butir soal atau $40 \%$ soal tergolong sukar, dan 12 butir soal atau $20 \%$ soal tergolong kategori sangat sukar.

Hasil analisis daya beda butir soal, diketahui bahwa 39 butir soal atau sebesar $65 \%$ soal termasuk kriteria jelek sekali. Sebanyak 17 butir soal atau sebesar $28,33 \%$ soal termasuk kriteria jelek. 4 butir soal atau sebesar $6,66 \%$ soal termasuk kriteria cukup, dan tidak ada soal yang memiliki atau termasuk kriteria baik. Hasil analisis kualitas opsi didapatkan soal dengan kualitas opsi pengecoh yang tidak berkualitas adalah $36,6 \%$ dan yang berkualitas adalah $63,3 \%$.

Berdasarkan hasil penelitian yang diperoleh, maka penulis menyarankan untuk panitia divisi soal agar dapat mengetahui sejauh mana tingkatan soal dan pengetahuan peserta didik.Bagi guru diharapkan untuk dapat menyediakan sarana dan prasana untuk memenuhi kebutuhan peserta didik dalam melaksanakan olimpiade serta memperbanyak waktu pembekalan. Bagi peneliti lain diharapkan penelitian ini dapat menjadi bahan referensi untuk melakukan penelitian yang sejenis.

\section{REFERENSI}

Anita,. Tyowati, Sulis., dan Zuldafrial. 2018. Analisis Kualitas Butir Soal Fisika Kelas X Sekolah Menengah Atas. Tingkat Kesukaran dan Daya Pembeda Soal Olimpiade Matematika (OMI) Tingkat SMP Tahun 2018. Jurnal Pendidikan, 35-47.

Arifin, Z. 2014. Evaluasi Pembelajaran. Bandung: Remaja Rosdakarya.

Arikunto, S. 2015. Dasar-Dasar Evaluasi Pendidikan. Jakarta: Bumi Aksara. 
Azwar, S. 2009. Reliabilitas dan Validitas. Yogyakarta: Pustaka Pelajar Offset.

Dewi, S. S., Hariastuti, R. M., dan Utami, A. U. 2019. Analisis Tingkat Kesukaran dan Daya Pembeda Soal Olimpiade Matematika (OMI) Tingkat SMP Tahun 2018. Jurnal Pendidikan Matematika \& Matematika,15-26.

Maiza, R. 2013. Analisis Soal Butir Tes Tertulis Tingkat SMP Pada Olimpiade Fisika Se-Riau Tahun 2013. Jurnal MIPA, 1-11.

Miranti., Fauziah, Y., Darmawati. 2019.Analisis Kualitas Soal Tes Tertulis Tingkat SMA Olimpiade Biologi Se-Riau dan Kepulauan Riau Tahun 2018 Berdasarkan Ranah Kognitif.Jurnal FKIP UR,. 1-10.

Nurinda, S., Rudyatmi , E., dan Ridlo, S. 2014. Analisis Butir Soal Olimpiade Biologi SMA Tingkat Kabupaten/Kota Tahun 2013.Journal Of Biology Education, 77-84.

Purwanto. 2013. Evaluasi Hasil Belajar. Yogyakarta: Pustaka Pelajar.

Sari., S, W., 2016.Penguasaan Materi Peserta dan Kualitas Soal Olimpiade Sains Biologi SMA Tingkat Kota Sawahlunto Tahun 2015. (1-11). Padang: STKIP PGRI Sumatera Barat.

Sofiana, S. 2010. Analisis Butir Soal Ulangan Kenaikan Kelas Mata Pelajaran Kimia Kelas X SMA Negeri 8 Surakarta Tahun Ajaran 2009/2010. Skripsi. Surakarta: Universitas Sebelas Maret.

Sukardi.2012. Evaluasi Pendidikan \& Prinsip Operasionalnya. Jakarta: Bumi Aksara.

Sudijono, A. 2012.Pengantar Evaluasi Pendidikan. Jakarta: Raja Grafindo Persada

Suwarto. 2016. Karakteristik Tes Biologi Kelas 7 Semester Gasal. Jurnal Penelitian Humaniora, 1-9. 